\title{
Swedish Language
}

National Cancer Institute

\section{Source}

National Cancer Institute. Swedish Language. NCI Thesaurus. Code C154146.

A North Germanic language spoken as the official language of Sweden. 